\title{
Directions of perfecting gene pool of equines of Ukrainian riding breed
}

\author{
I. Tkachova, \\ Candidate of Agricultural Sciences \\ Institute of Animal Science, National Academy of Sciences of Ukraine
}

The purpose. To determine directions of formation of selection attributes on the basis of analysis of modern state of equines of Ukrainian riding breed and ways of its further perfecting. Methods. Zootechnical, genealogical. Biometrical analysis of data was carried out with the help of statistical methods and program VIOM. Results. The methodology of building of equines of Ukrainian riding breed is analyzed, volumes of selection operation with the breed with the purpose of development of its gene pool in a direction of heightening sports work capacity and with simultaneous saving of original parentage, type, and exterior are studied. The previous period of implementation of programs of selection is analyzed and ways of its further perfection in view of demands of the inner and outer markets are specified. Conclusions. As the basic method of perfecting Ukrainian riding breed they specified pure breeding with the purpose of martemperingselection attributes. It is expedient to use moderately breed crossing with the best representatives of output and other sports breeds of world gene pool at the level of blood adding. For saving genetic diversity in breed in the proximal years they will allocate not less than 5 continuers of each line and 2 new genealogical lines will be approved: Raufbold and Eola. The positive trend of evolution of parent families is prolonged and amount of nested mares in parent content is increased.

Key words: equines, Ukrainian riding breed, stud farm, pedigree reproducer, selection, selection program, sports work capacity.

In 2015, it has been 70 years since inception, and 25 years since approval and adoption of the national unique breed of horse for sports purposes - Ukrainian riding horse. The official date of approval of the species -17 December 1990, but its history is much older [1].

Competing of foreign breeding horses with national, socio-economic restructuring, changes in ownership, economic crisis and other existing factors defined the problem of preservation of breeds of domestic breeding particularly important. From the solution of this question depends the fate of breeds of horses, which are traditionally bred for many years in our country, especially Ukrainian riding horse, characterized by superior features, which are typical for horses of global gene pool.

Work to create a new breed group was carried out in stages.

Phase I (1945-1951 years) - gathering of horse's reproductive structure on the plant and finding ways of crossing. This period is characterized by the trial of different variants of crossing, selection of qualitative breeding material [2].

Phase II (1952-1960 years) - desired type horse breeding. This step was characterized by the creation on the basis of a horse group, horses of Riding large sport horse type. This period coincided with reformulation of cavalry, the development of industry and mechanical engineering, that's why mass horse business needed reorientation to horse riding sport [3].

Phase III (1961-1975 years) - improvement of Ukrainian riding horses. This stage is characterized by stabilization of Ukrainian riding horse group genotype by means of complicated reproductive crossbreeding and breeding hybrids of desired type. Methodical and scientific management of breeding to create a new breed group in this period was entrusted to the Head of horse department of the Research Institute of Animal forest-steppe and Polesie SSR (now the Institute of Animal Science UAAS) D.A. Volkov [4-6]. The purpose of the work was the binding of complex selection features, ordering of pedigree 
records, development of methods of assessment of stallion sires on the quality of offspring sport features, identification of the best genealogy combinations, development of rebound schemes, mainly from dilution method "in itself". In breeding work combinational compatibility of constitutional, exterior and sporting qualities of horses of source breeding were taken into account: liveliness and breeding - Thoroughbred horse, jumping and motor skills - Trakenen and Hungarian, caliber and massiveness - Hanover, elegance exterior and riding qualities - Russian horse.

Phase IV (1976-1990 years) - Ukrainian horse riding breed testing [7]. At the beginning of testing horses belonged to various genealogical complexes and had a clear linear structure (Table. 1).

1.Genealogical complexes of breeding mares at studs (1976).

\begin{tabular}{|l|c|c|}
\hline \multicolumn{1}{|c|}{ Genealogical complexes } & \multicolumn{2}{c|}{ Number of mares in } \\
\cline { 2 - 3 } & studs \\
\hline English-Hungarian-trakeno & 42 & 20,39 \\
\hline English-Hungarian-Hanover & 25 & 12,14 \\
\hline English-Hungarian & 33 & 16,0 \\
\hline English-trakeno -Hannover-Hungarian & 18 & 8,73 \\
\hline English-Russian-Hungarian-trakeno & 18 & 8,73 \\
\hline English-Russian- trakeno & 5 & 2,42 \\
\hline Hungarian-trakeno & 8 & 3,88 \\
\hline Trakeno Hannover-Hungarian & 5 & 2,42 \\
\hline Russian-Hungarian-trakeno & 4 & 1,94 \\
\hline Russian-trakeno Hannover-Hungarian & 4 & 1,94 \\
\hline II-IV generation of hybrids with thoroughbred riding breed & 13 & 6,31 \\
\hline Other combinations & 31 & 15,1 \\
\hline \multicolumn{1}{r}{ Total } & $\mathbf{2 0 6}$ & $\mathbf{1 0 0}$ \\
\hline
\end{tabular}

In 1978-1979 control monitoring of horses was conducted and arrangements were made for organization of breeding job on horse plants of collective farms and state farms. On 01.01.1980, in Ukraine there were 2,711 purebred horses of Ukrainian riding breed group including 158 stallions and 2553 mares. Olympic Games in Moscow in 1980 and marvelous performance of the USSR team on horses of Ukrainian riding breed group influenced the fact that the number of horses began to increase.

Due to the increasing demands of equestrian sport and export, the breed was improved according to complex traits that define sports workability: type, measurements, exterior, quality movements, jumping quality [8].

In 1986 breeds have been prepared for approbation in accordance with the valid regulations of materials submitted to the State Agricultural of USSR. The number of the stock on 01/01/1986 was presented in Table 2.

2. The size of the breeding nucleus of Ukrainian breeding group at the beginning of approbation.

\begin{tabular}{|c|c|c|c|c|c|}
\hline \multirow{2}{*}{ Groups of horses } & \multicolumn{2}{|c|}{ At studs } & \multicolumn{2}{|c|}{ On pedigree farms } & \multirow{2}{*}{ Total } \\
\hline & голів & $\%$ & голів & $\%$ & \\
\hline Stallion sires & 22 & 48,9 & 23 & 51,1 & 45 \\
\hline Mares & 255 & 42,1 & 350 & 57,9 & 605 \\
\hline Youth & 523 & 52,7 & 470 & 47,3 & 993 \\
\hline Total & 800 & 48,7 & 843 & 51,3 & 1643 \\
\hline
\end{tabular}

The first significant performances in horses sports riding of Ukrainian riding group that was deduced, started simultaneously with the start of planned pedigree breeding. For the first time the horse of national 
selection breeding, stallion Satrap, born in 1948 from Ukrainian stud number 173 under the saddle of master of sports M.F. Shelenkova participated in the Olympic Games in 1956 in Stockholm triathlon. In the end, the Soviet team won seventh place with that in the toughest competitions with 19 teams participating, only 11 finished.

Later in Ukraine were grown a group of outstanding horses of domestic breeding, including champions of the Olympic Games and international competitions of the highest level. They are: Ichor, br., 1958 (T 54 Hobot - 86 Infra I) - Olympic champion in 1968 in Mexico City. Olympic Champion in 1972 in Munich; 97 Plot, blk., 1966 (77 Tuman - 131 Pyramida) - Olympic champion in 1980 in Moscow; 52 Ihrok, br., 1968 (3016 Gunib - 87 Infra II) - Olympic champion in 1980 in Moscow; Squall, b., 1970 (8 Kokhanyy - 208 Sherenga) - Olympic champion in 1980 in Moscow; 72 Rukh, ch., 1973 (54 Hobot T - 148 Raduga) Champion of alternative games "Druzhba-84"; 7 Izhyb, b., 1952 (Istok - Vega) - an outstanding stallion, sire, winner of Eney degree in 1964; 55 Ishod, b., 1956 (54 Hobot T - 368 Izyda) - an outstanding stallion, sire; 56 Ihvan, b., 1961 (54 Hobot T - 86 Infra I) - an outstanding stallion, sire, follower of Hobot line; 8 Kokhanyy, ch., 1963 (54 Hobot T - 95 Colonnade) - an outstanding stallion, sire; 9 Potash, b., 1950 (Poseydonius - Prose) outstanding stallion, sire; 10 Reserve, ch, 1966 (Hobot T 54 - 151 Riga) - an outstanding stallion, sire; 6 Sbornik, br., 1966 (2 Bezpechnyy - 76 Zvozdochka) - Champion of the breed in 1969 , an outstanding stallion, sire, and others.

With the independence of Ukraine in the economy of the country started economic restructuring. Since the beginning of economic reforms in Ukraine, its agricultural sector especially, the population of horses in Ukraine has undergone considerable reduction - almost 50\% over the past 20 years. Those years were a turning point in the fate of many athletes horsemen, infrastructure collapsed and trained equestrian sport horses of international level massively sold abroad where they were in great demand. However, Ukraine has preserved much of valuable gene pool of the species and continued its improvement.

After approval the first testing Program of breeding Ukrainian riding breed selection was approved in 1994 [11]. The breeding nucleus of Ukrainian riding breed consisted of 50 stallions sires and 432 breeding mares. The main objective of the program was to preserve and improve the exterior and sportqualities, breed stallion sires taking into account breed association and saturation of pedigrees with specific breed combinations, genealogical complexes, progenitors of lines related groups, mother families.

While fulfilling the selection program in 2003-2010 the breeding nucleus of Ukrainian riding breed widened and consisted of 38 stallion-sires and 533 pedigree mares [12]. In this period the National certification of stallion sires before using was introduced. Pedigree work with breed was directed towards the preservation of exterior peculiarities, original type, improvement of pedigree qualities, increase of sport workability. The main method that was used - pure breeding with wide usage of pedigree, typical stallion sires, that have ancestors in Russian riding horse (Orlov-Rostopchin) breed with conditional heritage $1 / 8-3 / 16$ and higher [13].

A purpose of researches is definition of directions of formation of selection traits on the basis of the analysis of the current state of the Ukrainian horse breed horses, and determine ways of its further development.

The materials and methods. In recent years, rating of the results of breed performances of our riders in international competitions in classical types of equestrian sport hasn't significantly improved. Against the background of unstable economic conditions, with the presence of valuable breeding material, subjects breeding are not always able to provide the proper execution of the technological requirements of growing, training and trials of horses, to send their horses to any international competition.

The results of the research. At the same time there are certain achievements. Ukrainian athletes horsemen entered the ranking of the European Equestrian Federation (EEF) riding national selection horses. For the first time since independence of Ukraine national pair took part at the Olympic Games (London 2012, Great Britain)i. Ukrainian horsemen repeatedly participated in international competitions of high level, won prizes: International riding competitions CDI ${ }^{* * *}$ (Ahlyayten Austria), International riding competitions CDI *** (Wroclaw, Poland), International Tournament CDI-W (Mechelen, Hungary), 
President's Cup (Moscow, Russia), International Tournament, triathlon SSI1 * (Moscow, Russia) Tournament Riding CDI-W (N.Novgorod, Russia), World Cup, triathlon SSI1 * (Belarus), International Riding Tournament (Radzenkuv, Poland) and others.

On 01.01.2015 in Ukraine are registered 25 entities of breeding Ukrainian riding breed, including 7 stud farms and 18 breed reproducers. Number of horses is 1368 heads, including 38 stallions sires and 533 breeding mares (Table. 3). Also in this breed work involved with the breed 9 stallions sires are used of Western Europe sporting breeds and 2 - Thoroughbred horse, 183 Western Europe sporting breeds and 27 - Thoroughbred horse breeds.

3. The size of the Ukrainian horses of riding breed on 01/01/2015.

\begin{tabular}{|c|c|c|c|c|}
\hline \multirow[b]{2}{*}{ Subject of pedigree work } & \multirow[b]{2}{*}{$\mathbf{n}$} & \multicolumn{3}{|c|}{ у т. 4.} \\
\hline & & $\begin{array}{l}\text { Stallion } \\
\text { sires }\end{array}$ & mother & youth \\
\hline Ukrainian riding breed & 114 & 38 & 533 & 698 \\
\hline Horse studs & 735 & 15 & 293 & 427 \\
\hline Pedigree reproducers & 545 & 31 & 240 & 274 \\
\hline $\begin{array}{l}\text { Outcome of breeds, approved for } \\
\text { reproduction }\end{array}$ & 221 & 11 & 210 & - \\
\hline Total: & $\begin{array}{l}136 \\
8\end{array}$ & 49 & 743 & 698 \\
\hline
\end{tabular}

The main indicator of activity of subjects of breeding on breeding Ukrainian riding breed is growing of high quality pedigree production and sport horses. For 20-year period (1993-2013) subjects of breeding of Ukrainian riding breed have grown 86 stallion sires prepared to classical types of equestrian sport 359 horses. The ratio of horses in this period in the different types of horse sport is the following: show jumping - $169(47.1 \%)$, riding - $159(44.3 \%)$, triathlon - 31 (8.6\%).

Since its testing genealogical structure has undergone some changes. Analysis of the origin of stallions and mares by sires genealogical structure makes it possible to determine the next trend in the genealogical structure of the breed (Fig. 1).

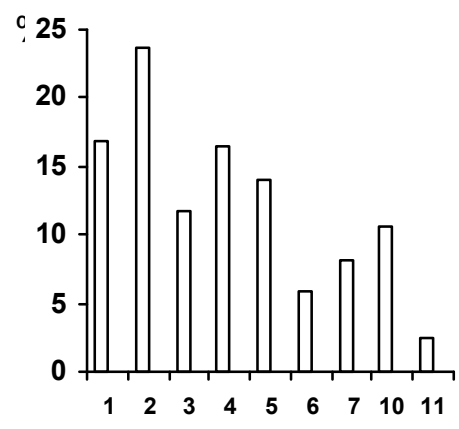

1986

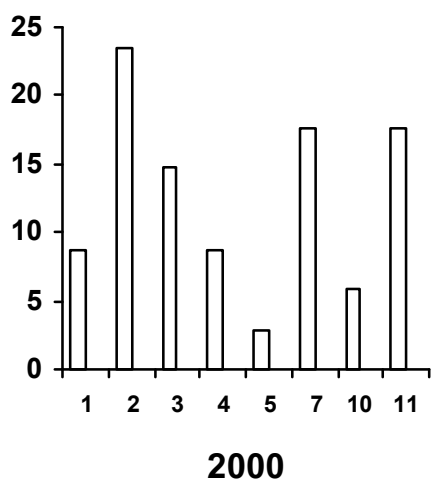

2000

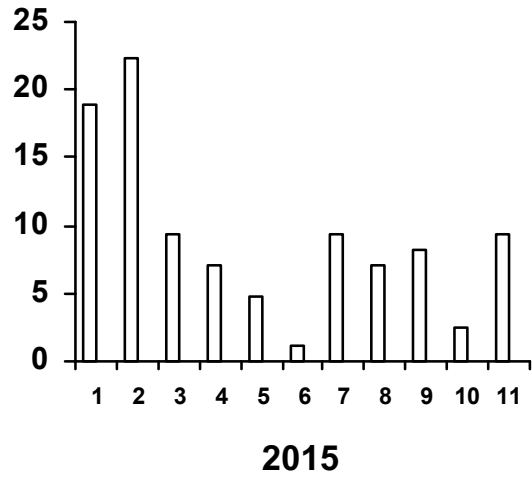

2015

Signs, lines: 1 - Bezpechnyy, 2 -Hobot, 3 - Factotum, 4 - Gugenot, 5 - Khrustal, 6 - Vodopad; related groups: 7 - Rauphbold, 8 - Eola; Stallio sires: 9 - non-linear of national selection; 10 Thoroughbred and Arabic breed; 11 - Western Europe sport breed.

Fig. 1. Dynamics of genealogical structure of Ukrainian riding breed 
It is noticeable that by 2010 there was a steady increase in the number of stallion sires and mares as a whole pedigree, and on separate lines, related groups and descendants of nonlinear domestic origin and West-European stallions. Subsequently, the number of sires and mares in all structural units slightly decreased. From each line precious continuators and sport horses are received, but the leading ones in breed are Bezpechnyy and Hobot, which are with regard to the number of successors, assessment for complex traits exceed the minimum requirements for structural breed units.

The largest number of breeding mares also comes from Hobot lines (20.2\%) and Bezpechnyy (15.6\%), most of them also come from precious mother families and their nests. Almost all valuable stallion sires and high quality sport horses originate from mothers' families.

During the period of formation of Ukrainian riding breed (1952-1990 gg.) it was established 25 mother families. Today their number increased to 31. The biggest number of mares (over 10 heads) in mother families of Arizona, Themes, Bilinka, Infra I, , Hohlatka, Bahroma, Maritsa. Top performance measurements are mother families of Themes (166-197-20,7 cm) infrastructure and (167-198-20,5 cm), Infra I (166-198-20,6 cm). The best on the number of products and breeding sport horses are families of Arizona, Azaleas, Bilinka, Briga, Gvozdika, Infra I, Kafedra, Maritsa, Nona, Raduga, Themes.

During the period, when the state certification of stallions sires was introduced (2005-2013 years), for reproduction of horses of Ukrainian riding breed 199 stallions sires were certified, including 128 of Ukrainian riding horse $(64.3 \%)$ and $71(35.7 \%)$ - other riding species.

Dynamics of usage of import sires tend to increase. Thus, in 2005, 9 stallions of Western species were involved in pairing, or $18 \%$ of all livestock producers. In 2010 , this indicator was -- 8 heads and $12.5 \%$ of the total population. In 2013 - seven heads and 12.5\%. Among the stallions of other breeds the majority are of Westphalian breed: Artifeks, gr., 1999 (Ars Vivendi - Cantara), born in Germany - winner of the Grand Prix Championship and the Cup of Ukraine, Cardinal, Consolidator, Copperfield, Cupid, Kaiser, Moon Ray - the sons of Cornet Obolenskyy - the participant of Olympic Games in Beijing in 2008, the sons of Lancer - Holstein kiering winner, stallion that is the part of the world's top ten sires of riding species: Leipzig, Lido.

In today's uterine composition 126 mares are used, obtained from the use of stallions of output and other riding breeds, including the Thoroughbred riding breed stallions - 14 heads, 40 heads of Trakenen, Hanover - 32 heads, Westphalian - 40 goals.

Mother composition of Ukrainian riding breed in general suits to the requirements of the selection. High appreciation of pedigree and the desired type have daughters of stallion sires LLC "Kharkiv stud": Arshin, Areal, Tarbahan, Bismark and branch of SOE "Horse breeding of Ukraine": "Alexandria stud № 174" - Bushprita, Shablon; "Lozovskiy stud № 124" - Tembr, Hiton, Obrazets, Boryspil; "Dnepropetrovsk stud № 65" - Borispol, Playboy, Ahiney.

Analysis of the level of reproduction of Ukrainian riding breed over the last 10 years in the breeding studs and reproducers indicates that this feature is strongly influenced by the year of foaling. Exit of foals over the years in studs is - $52,8-64,7 \%$ in pedigree reproducers - $37,4-71,6 \%$.

The system of evaluation of signs at appraisal of Ukrainian riding breed horses takes into account the following features: the origin; expressiveness of desired type of body structure; measurements (according to the breed standard by age periods); evaluation of exterior for active scale; evaluation of active sport workability that works according to the system of tests; evaluation of sires and mares according to the quality of offspring; assessment of stallions sires for prepotentes (ratio of the average appraisal point of offspring from stallions sire to similar mothers of the offspring).

Selection program 2020 established the following selection indicators [14]:

- Purpose and direction of the performance - pedigree horses mainly for pure breeding, horses of high sports class with universal sports workability;

- Methods of breeding of Ukrainian riding breed - for pure breeding according to the lines, crossing at the level of blood transfer with source and other sports pedigrees, type of body structure, exterior and labor productivity similar to Ukrainian riding breed and able to improve its breeding characteristics. For 
reproduction of Ukrainian riding breed sires of other sporting breeds are allowed only if they match the type of growth, conformation and outstanding sports performance operability. Conditional heritage of mixed breeds for the given breeds should not exceed $3 / 4$, other improving species of appropriate type - $1 / 2$;

- Breeding nucleus must be at least 800 purebred mares;

- The amount of genealogical lines - 7; number of stallion sires in lines - at least 5 mares - 30 heads;

- Performance measurements of horses of different gender and age groups, according to the standard of breed (withers height, oblique body length, chest girth, metacarpus girth) horses of 2 years old: 160$158-178-20 \mathrm{~cm}$ ( stallions) 157-155-177-20 cm (mares); horses of 3 years old: 163-162-186-21 cm (stallions) 161-160-184-20,5 cm (mares); horses of 4 years of age and older: 165-165-192-21 cm (stallions) 163-163-190-20,5 cm (mares);

- Young class of the first appraisal should be: the elite - 85\%, $1 \mathrm{cl}$ - $15 \%$ (youth); elite - $90 \% 1 \mathrm{cl}$ $10 \%$ (mares);

- For the selection to reproductive structure the GPA for sports workability of two-year-old calves must be not lower than 8 points (youth), 7 points (mares);

- The proportion of horses that have passed factory and respective Inter-Enterprise tests of sport qualities: for stud farms - $80 \%$; pedigree reproducers - $70 \%$;

- the height of overcoming obstacles during the test of jumping skills on the loose (without rider): aged 2 years $-130 \mathrm{~cm}$; aged 3 years $-140 \mathrm{~cm}$; aged 4 years and older $-150 \mathrm{~cm}$.

\section{Conclusions}

1. The main method of improvement of the Ukrainian warmblood breed purebred identified breeding lines, breeding work aimed at preserving the characteristic features of the original type of the body structure, elegant exterior forms, and a significant increase in athletic performance.

2. The purpose of qualitative improvement of breeding grounds, including athletic performance, it is advisable to moderate the use of crossbreeding with the best representatives of weekends and other sporting breeds of the world gene pool at the level the bloods of.

3. Ukrainian warmblood breed of the modern population has a well developed genealogical structure. To preserve genetic diversity in the breed in the coming years will be allocated not less than five followers each line and tested two new genealogical line: Raufbold and Eol.

4. In the rock extended a positive trend in the development of Royal families, the increase in the number of breeding mares in the fallopian composition of the rocks. A particularly valuable genotype of the different Royal families with the presence of the ancestors of Russian horse (Orlov-Rostopchin) breed: 318 blade of grass, Cloves 61, in which the same is received for outstanding work-sports horses and stallions prepotentes and family, who often get outstanding work-sports and breeding qualities of horses: 266 Arizona, 85 Infantry, 86 Nfri And Cantl 89, 91 Department of, 104 Maritza, Nona, Odra 426, 433 Pafa, 148 Raduga, 159 Thema, 160 Tina, 541 Khokhlatka.

\section{Bibliography}

1. Ukrayins'ka verkhova poroda: monohrafiya/D.A. Volkov, I.V. Tkachova, O.M. Latka ta in.; za red. I.V. Tkachovoyi. - Kh.: Instytut tvarynnytstva NAAN, 2014. - $218 \mathrm{~s}$.

2. Sen'kovskyy E.Y. Plemennoe verkhovoe konevodstvo Ukraynskoy SSR/E.Y. Cen'kovskyy/l Konevodstvo. - 1946. - № $8-9$. - S. $33-38$.

3. Belan P.Ya. Ukraynskaya verkhovo-upryazhnaya hruppa loshadey/P.Ya. Belan//Sots. tvarynnytstvo. - 1956. — № 12. - S. 31.

4. Volkov D.A. Plemennaya rabota s ukraynskoy verkhovoy porodnoy hruppoy loshadey/D.A. Volkov, P.P. Volkov//Konevodstvo y konnыy sport. - 1963. — \# 11. - S. 8 - 10.

5. Volkov D.A. Puty sovershenstvovanyya novoy ukraynskoy verkhovoy porodnoy hruppы verkhovыkh loshadey/D.A. Volkov//Voprosы yntensyfykatsyy zhyvotnovodstva: sb. nauch. tr./NYY zhyvotnovodstva Lesostepy y Poles'ya USSR. — Kh., 1969. - T. 35. - S. 240 - 251. 
6. Volkov D. A. Ukrayins'ka verkhova poroda koney/D.A. Volkov//Konyarstvo. — K.: Urozhay, 1971. — S. $103-104$.

7. Materyalы k aprobatsyy ukraynskoy verkhovoy porodы loshadey/D.A. Volkov//MSKh USSR. — Kh., 1981.

8. Metodycheskye rekomendatsyy po plemennoy rabote s loshad'my ukraynskoy verkhovoy porodnoy hruppы/D.A. Volkov, A.S. Fylymonova, A.A. Novykov. - Kh.: NYY zhyvotnovodstva Lesostepy y Poles'ya USSR, 1982. - $19 \mathrm{~s}$.

9. Volkov D.A. Ukraynskaya porodnaya hruppa/D.A. Volkov//Konevodstvo y konnыy sport. - 1986. — № 11. - S. $9-12$.

10. Novaya verkhovaya poroda loshadey/D.A. Volkov, V.A. Lebedev, A.M. Latka [y dr.]//Nauch.-tekhn. byul. - Kh.: NYY zhyvotnovodstva Lesostepy y Poles'ya USSR, 1991. — № 59. - S. $45-52$.

11. Программа селекции украинской верховой породы лошадей/Д.А. Волков, А.А. Калантар, А.М. Латка и др. - Х., 1994. - 15 с.

12. Mel'nyk Yu.F. Prohrama selektsiyi koney ukrayins'koyi verkhovoyi porody na $2003-2010$ roky/Min-vo ahrar. polityky Ukrayiny, Korporatsiya «Konyarstvo Ukrayiny»; Yu.F. Mel'nyk, D.A. Volkov, O.O. Novykov, ta in. - K.: Ahrar. nauka, 2003. - $94 \mathrm{~s}$.

13. Latka O.M. Udoskonalennya ukrayins'koyi verkhovoyi porody/O.M. Latka//Tvarynnytstvo Ukrayiny. - 2007. — № 4. - S. 12 - 14.

14. Prohrama selektsiyi koney ukrayins'koyi verkhovoyi porody do 2020 roku/N.V. Kudryavs'ka, O.M. Zhukors'kyy, O.I. Kostenko ta in.; za red. N.V. Kudryavs'koyi, I.V. Tkachovoyi. - Kh.: Instytut tvarynnytstva NAAN, 2015. - $69 \mathrm{~s}$. 